\title{
Relationship Between Financial Regulation and Microfinance Institutions Sustainability and Outreach in Northern Ghana
}

\author{
Dr. Issahaku Salifu ${ }^{1^{*}}$ Dr. Boadu Ayeboafo ${ }^{1^{*}}$ \\ 1.Faculty of Business, Tamale Technical University, P. O. Box 3, E/R, Tamale, Northern Region, Ghana \\ 2.Faculty of Business, Kumasi Technical University, P. O. Box, Kumasi, Ashanti Region, Ghana
}

\begin{abstract}
Purpose: This study examined the relationship between financial regulation of microfinance institutions and their sustainability and outreach from the view point of managers and operation staff in northern Ghana.

Methodology: The study used primary data. Purposive and convenient sampling techniques were used in selecting 189 managers and operating staffs across 18 microfinance institutions operating in northern Ghana. In addition, the researchers purposively sampled 5 experienced senior staff from the Bank of Ghana. Data was collected using structured questionnaires, which was personally administered by the researchers and two research assistants. Research assistants were trained by the researchers on the ethics of this study before and during the data collection process. Data collected was analysed using Spearman's correlation and descriptive statistics.

Findings: The study found positive statistically significant relationship between financial regulation and financial sustainability and outreach among managers and operation staff of MFIs surveyed in northern Ghana. The study further found that financial regulations of MFIs in northern Ghana affected sustainability and outreach.

Originality: This study adds to the literature on financial regulation and microfinance sustainability and outreach in the context northern Ghana.

Limitations: This study is limited to only northern Ghana and not Ghana in its entirety. The study was delayed due to publication processes and other factors and changes might have taken place in the microfinance industry in northern Ghana. However, this notwithstanding, the results of the study are still relevant for publication.
\end{abstract}

Keywords: Financial regulation, Sustainability, Outreach, Ghana, Microfinance institutions.

DOI: $10.7176 / \mathrm{EJBM} / 11-25-10$

Publication date:September $30^{\text {th }} 2019$

\section{Introduction}

Several social intervention programmes, including the Livelihood Empowerment against Poverty (LEAP), Capitation Grant, School Feeding Programme, free distribution of school uniforms, exercise books and textbooks, elimination of schools under trees, have been implemented with the aim of alleviating poverty among the vulnerable population in Ghana in the past twenty years. Other projects aimed at improving health care delivery have also been implemented. These include the establishment of Community-based Health Planning Services (CHPS), national immunization against polio and indoor residual spraying against malaria carrying mosquitoes (Ghana Living Standard Survey Report, 2014). The above notwithstanding microfinance is one of the most prominent and most effective interventions as far as poverty reduction is concerned and as a result, its sustainability in Ghana and in particular the poorest regions (northern Ghana) cannot be overemphasized.

Microfinance is banking for the poor people in society, in particular developing countries including Ghana. Microfinance Institutions (MFIs) are institutions that provide financial services such as credit, savings and insurance to low income clients who traditionally lacked access to credit, banking and related services (Akinosi, Nordlund \& Turbay, 2011). Nurmakhanova, Kretzschmar and Fedhila (2015) define MFIs as those offering banking services to the poor customers who have no access to the traditional financial sector. MFIs provide financial services to the low-income households in developing countries around the world (Bogan, 2012).

The main objective of most MFIs is to reduce poverty in society. Poverty is defined by the UN (2005) as deprivation of necessary power, source and capability to have a decent live and to actualize the political, economic and social rights (Davutoğlu, 2013). Although MFIs argue that they work to promote financial inclusion by delivery of financial services at affordable costs to sections of disadvantaged and low-income segments of society but the interest rate offered by MFIs does not suggest that is really the case (Akinosi, Nordlund \& Turbay, 2011).

In Ghana, the practice of sourcing funds from non-formal financial institutions dates back to 1955, when the Canadian Catholic Missionaries established the first credit union in northern Ghana. The concept was expanded at the beginning of the 1970s with the establishment of the first rural bank at Nyakrom. Since the activities of such institutions were not considered as part of mainstream financial sector, their contribution to financial deepening was neither documented nor recognized until the latter part of the 1990s, when issues of poverty reduction became part of developmental agenda. The shift from growth-led strategies to poverty reduction strategies provided an avenue for pro-poor policies and programmes. Recognizing access to credit as a major constraint to the promotion of pro-poor activities, a number of institutions (governmental and non-governmental) emerged to provide financial services to the poor (Annim, 2011; Aveh, 2011) 
The Microfinance Action Research Network (MFARN) was established in 1996 by a number of groups involved in the implementation of microfinance projects. The main objective of MFARN was to actively play a very critical role in the discussion, formulation and implementation of microfinance related programmes throughout Ghana. MFARN was changed to Ghana Microfinance Institutions Network (GHAMFIN) in 1998. GHAMFIN had the following objectives according to Annim (2011):

1. To contribute to the creation of employment opportunities for Ghanaian people

2. Provision of support and empowerment to the poor and financially excluded.

3. To sensitize government and stakeholders of microfinance in Ghana.

4. To strengthen the capacity of MFIs through training.

As part of its efforts in reducing poverty, the government of Ghana has initiated microfinance projects in a number of ministries, departments and agencies (MDA). Among the MDA with microfinance programmes are Ministry of Finance and Economic Planning, Ministry of Women, Gender and Social Protection, Bank of Ghana, Ministry of Local Government and Rural Development. In order to co-ordinate and streamline activities of the industry, a central body, known as the Microfinance and Small Loans Centre (MASLOC) was established in 2006. Its mandate is to co-ordinate all microfinance activities in the country especially government programmes and complement the activities of other microfinance apex bodies (Annim, 2011; Aveh, 2011).

In Ghana, the number of institutions that are involved in the provision of microfinance services are categorized into five namely Rural and Community Banks (RCBS), Savings and Loans Companies (S \&Ls), Financial Nongovernmental Organizations (FNGOs), Credit Unions and Susu Collectors Association of Ghana. All these institutions have presence in all the ten regions in Ghana. Additionally, Annim (2011) indicates that some formal banks and insurance companies have either linked up with existing microfinance institutions or created a microfinance department in order to also provide microfinance services. The heightened interest and concerns of microfinance activities in Ghana drives the exploration of complementary services and signals the need for market growth towards competition. Stakeholders' sustained interest and concerns are partly explained by the perceived availability of effective demand for financial services (Aveh, 2011; Annim, 2011; Yeboah, 2010).

The practical problem of high interest rate has been a debate in the microfinance industry the world over. Bogan (2012) contends that in order to cushion themselves from perceived risks due to the target client's lack of collateral as a guarantee against default, MFIs are known to charge very high (30-60\%) nominal interest rates. The loans are short term, the average loan size is very small, and only a few programs require borrowers to put up collateral (Bogan, 2012). In Ghana, the situation is not different either and this is because MFIs charges interest rate as high as between (30-60\%). Similarly, these MFIs also offer their clients attractive interest rates on their deposits of between averages of $(40-50 \%)$ over a three-month period, which most end up to able to pay and they collapse in the process thereby forcing the government to enact legislations in response. Many genuine investment instruments on the market are benchmarked with the Bank of Ghana Treasury Bill rate which is presently the most risk-free investment instrument in Ghana but do not offer such attractive rate of interest. The problem is whether or not the Bank of Ghana as a regulator and supervisor know of this trend prior to MFIs offering such attractive but unachievable interest rates to their customers.

The proliferation of MFIs is posing supervision challenges for the Bank of Ghana and as a result allow fraudulent operatives in the industry aimed at defrauding unsuspecting public. There have been very high microfinance failures in Ghana leading to the loss of millions of Ghana cedis by depositors. The most popular among them is the DKM microfinance failure in 2016 which caused a lot of pain and loss of investments across the country, and in particular the Brong- Ahafo Region of Ghana. In fact, some people lost their lives and it became a serious political debate in Ghana. DKM Diamond Microfinance, an MFI in Ghana with its main head office located in the Brong Ahafo Region, offered clients high interest rates between 50 and 55 per cent and collected money from customers over a period. DKM, according to President Mahama, diverted a whopping GH $\notin 77$ million (USD \$ 22 million) of investors' funds into its subsidiary firms, leading to the inability of the firm to pay returns to clients, some of whom have died or committed suicide as a result of the anguish they suffered in connection with what was more of a Ponzi scheme (GHAFIN, 2016).

After the DKM failure, the Bank of Ghana has since revoked 70 MFIs licenses for breaching the Central Bank regulations making their activities illegal. The truth is that there is a lot of tension and mistrust among MFIs and their depositors. The President of the Republic of Ghana announced that DKM will be liquidated formerly and depositor's savings will be returned to them at the costs of the state. The liquidator appointed to oversee the DKM liquidation process announced in September, 2016 that government of Ghana has released an amount of GHC540 million Ghana Cedis an equivalent of USD\$138.5 million (using an exchange rate of GHC3.9 to the \$1). Initially, the government underestimated the amount involved to be just USD\$22 million which amounted to GHC77 million. The payment to beneficiaries is expected to be completed by the end of October 2016 .

In all of these, how has regulation impacted on the successful operation or otherwise of the MFIs in Ghana. The problem however, is that most MFIs are profit making institutions who may end up extorting their clients if their activities are not checked and regulated by government. While poor regulatory regime may lead to depositors 
losing their savings to fraudulent MFIs on one hand, on the other hand, tougher regulatory regime may stifle MFIs from profitable and sustainable operations and cannot contribute to economic growth and development. Therefore, government must get the balance right of not regulating too much or too less to the mutual benefits of poor borrowers and the MFIs.

\subsection{Research objective}

The objective of this study is to examine the relationship between financial regulation of MFIs and their sustainability and outreach from the view point of managers and operation staff in northern Ghana

\subsection{Research Question and Hypothesis}

Is there a statistically significant relationship between financial regulation of an MFI sustainability and outreach from the view point of managers and operation staff in northern Ghana?

H1o: There is no statistically significant relationship between financial regulation of an MFI sustainability and outreach from the view point of managers and operation staff in northern Ghana

$\mathrm{H} 2 \mathrm{a}$ : There is a statistically significant relationship between financial regulation of an MFI sustainability and outreach from the view point of managers and operation staff in northern Ghana.

The rest of the paper is structured as follows: Literature review, methodology, presentation of findings, discussion of results, and conclusions and recommendations.

\section{Theoretical Framework and Literature Review}

This section reviewed the theoretical framework, defined financial sustainability and outreach and empirically reviewed literature on financial regulation and its impacts on sustainability and outreach of microfinance institutions. The section reviewed briefly the regulatory framework of MFIs in Ghana.

\subsection{Theoretical Framework}

This study is grounded by the agency and moral hazard theories.

\subsubsection{Agency Theory}

The agency problem is between a lender and a borrower (the MFIs and their clients). The borrower has a project, but no money to finance this project; he or she must then turn to the lender. The interests of MFIs management and those of social investors may not be aligned (Omondi, 2014). Aveh (2011) indicates that the agency problem refers to the lender's inability to observe the borrower's characteristics such as the project riskiness, borrower's efforts or profits. These information problems create inefficiencies and microfinance is one attempt to overcome the agency problem. In this case, the tension involves a principal (the lender) trying to do business with an agent (the borrower) (Aveh, 2011).

\subsubsection{Moral Hazard}

The incentive by the borrower (poor) who holds an asset belonging to the lender (MFI) to endanger the value of that asset because the borrower bears less than the full consequence of any loss is known as moral hazard (Chaves \& Gonzalez-Vega, 1994) as cited in Aveh (2011). A borrower's effort to repay may be largely unobservable by an MFI; it cannot readily determine what is attributable to the lack of effort by the client as opposed to bad luck or external forces (Aveh, 2011). Legerwood (2000) indicates that an MFI that could carefully observe and conduct a good credit assessment on the borrower could relate the terms of the loan contracts. However, because it is expensive to conduct a good credit assessment, most MFIs only ensure that cash flow and debt capacity of clients are sufficient that clients will repay loanable funds. MFIs must also set terms of the loan that are acceptable to the borrower and result in behavior that the MFI prefers only this way that will encourage clients to work hard in order to repay the loan.

\subsubsection{Adverse Selection}

The inability of MFIs to differentiate between the riskier borrowers and the non-riskier ones because of the lack of adequate information about the riskiness of the borrowers' projects result in the MFIs charging higher interest rates. Unfortunately, higher rates in turn drive worthy borrowers out of the credit market (Aveh, 2011). Consequently, this is a market "imperfection" since worthy borrowers do not participate in the credit market (Armendariz de Aghion and Morduch, 2005). As a result, inefficiencies due to adverse selection arise when banks cannot adequately distinguish safer borrowers from riskier borrowers. When that happens, all borrowers are charged the same interest rates, and safer borrowers end up effectively cross-subsidizing riskier borrowers (Aveh, 2011).

\subsection{Financial Sustainability}

Financial sustainability of MFIs is probably the major and most significant aspect of microfinance sustainability. The financial sustainability of an MFI can be defined as its capacity to cover all of its expenses by its revenue and to generate a margin to finance its growth. In other words, it is the capacity of an MFI to carry out its activities 
without the need for subsidies in the form of concessional loans or donations (Ayayi \& Sene, 2012). It refers to the ability of MFIs to cover all its costs from its own internally generated income from operations (Thapa et al., 1992; Nyamsogoro, 2010; Kinde, 2012) without depending on external support or subsidy.

\subsubsection{Outreach of Microfinance Institutions}

Social outreach generally refers to either breadth of outreach or depth of outreach, while occasionally it may also include outreach to women borrowers. Outreach to women is measured by the number of women borrowers as a fraction of the total number of borrowers (Quayes, 2012). Kaur (2014) contends that outreach is typically used to refer to the effort by MFIs to extend loans and financial services to an ever-wider audience (breadth of outreach) and especially toward the poorest of the poor (depth of outreach). Thus, reaching the poorest is depth of outreach, but reaching large number of people even if they are relatively less poor is breadth of outreach (Kaur, 2014). Hermes et al. (2011) express similar views on outreach. They argue that outreach is to provide credit to the poor who have no access to commercial banks, in order to reduce poverty and to help them with setting up their own income generating businesses. Schreiner (2002) provides somewhat more comprehensive definition of outreach and proposed outreach have six dimensions: Worth of Outreach, Cost of Outreach, Scope of Outreach, Depth of Outreach, Length of Outreach, and Breadth of Outreach.

\subsection{Empirical Literature on Regulation and MFIs Sustainability and outreach}

Regulation, especially of the financial sector including financial services and financial intermediaries has always been the concern of not only researchers and academia, but also regulating authorities, particularly governments across the world (Ranjani, 2012). According to various Consultative Group to Assist the Poor (CGAP, 2013, p.11) regulation of MFIs are a "set of government rules that apply to microfinance". Regulations are meant to protect the clients of MFIs, increase public and investor confidence thereby promoting fair competition in the microfinance industry. Consequently, regulations are also meant to provide an enabling environment for the smooth operation, development and growth of the microfinance industry around the world and in particular developing countries. Indeed, it has been argued that regulating MFIs has a potential to speed the emergence of sustainable MFIs (Mulunga, 2010; Nyamsogoro, 2010).

Internationally, the microfinance industry operates under different regulatory regimes depending on the country of its location and hence regulation and identification of regulatory authority has always been a challenge as far as the microfinance industry is concerned (Ranjani, 2012). Thus, Ranjani (2012) reports that the forms of organisations providing microfinance services in Bolivia are MFIs, NGOs, commercial banks, credit unions and private financial funds. Similarly, in Brazil, Ranjani (2012) indicates that State-owned development banks, Public Interest Civil Society (OSCIPs), Microenterprise Credit Society (SCMs) and commercial banks are responsible for the provision of microfinance services.

The microfinance sector in Indonesia comprises commercial banks, rural banks, non-bank financial institutions (leasing, factoring, consumer financing, and credit cards), pawnshops and various semi-formal and informal MFIs (Ranjani, 2012). In Ghana, however, the Ghanaian regulatory approach has fostered a wide range of formal and informal MFIs-rural banks (RBs), savings and loans companies (S\&Ls), credit unions (CUs), NGOs, community-based organisations (CBOs), small savings-credit associations and informal savings collectors and moneylenders (Ranjani, 2012).

As a result, regulation of MFIs may affect their sustainability either favorably or unfavorably to the extent that the benefits outweigh the costs and vice versa. This suggest therefore, that MFIs can really deliver services profitably to the productive poor when there is macroeconomic, political, legal, and regulatory enabling environment (Purkayastha, Tripathy \& Das, 2014; Ranjani, 2012; Nyamsogoro, 2010; Robinson, 2001). Unregulated MFIs according to Borgan, (2012) and Bogan et al. (2007) have restricted access to financing options, that is, limited sources of capital to operate with, which can have huge implications on the sustainability and outreach of these institutions.

Indeed, experience from Ghana and Philippines shows that the financial performance and sustainability profiles of regulated MFIs are significantly different in comparing the pre-and post-regulation performance, the reasons being, among others, higher base of unimpaired capital and ability of owners to step forward with additional capital (Aveh, 2011; Yeboah, 2010; Nyamsogoro, 2010; Gallardo, 2001). As a result, regulation helps in long-term sustainability, even though MFIs may fall under stringent regulation in the initial years. Regulation and supervision ensure that MFIs are run prudently and cases of poor people losing their money due to fraud or incompetence are reduced to the barest minimum (Kimando, Kihoro \& Njogu, 2012).

MFIs access to capital will enable them increase loanable funds, which may as a result enhance sustainability of these institutions, as they will be able to reach many poorer clients (Bogan, 2012). As indicated by Makame and Murinde (2006) that outreach and microfinance regulations were negatively correlated suggesting that regulating an MFI would reduce its focus to serving the poorer clients. The implication is that whilst MFIs increase their capital base because of regulation in order to guarantee depositors, at the same time this can result into a mission drift of an MFI from serving poorer clients to serving wealthier or average clients thereby reducing the depth of 
outreach. The impact of prudent regulation on profitability and financial self-sufficiency according to Purkayastha, Tripathy and Das (2014) reveals that rigorous and regular supervision is critical for deposit taking institutions, but it is costly and as a result, regulatory supervision thus tends to push institutions to serve relatively better-off customers as a way to maintain profitability.

In a study of 245 leading MFIs to understand the effects that prudent supervision may have of profitability of MFIs and outreach, Cull et al. (2011a) found that profit-oriented MFIs that must comply with prudential supervision respond by curtailing their outreach to segments of the population that are costlier to serve. However, MFIs that rely on noncommercial sources of funding (for example, donations), and thus are less profit-oriented, do not adjust loan sizes or lend less to women when supervised, but their profitability is significantly reduced. Split sample tests based on the share of funding that an MFI receives from noncommercial sources confirm this pattern of their findings.

On the one hand, on whether or not regulated MFIs achieve better sustainability and outreach than unregulated MFIs, Hartarska and Nadolnyak (2007) uncovered in their study that regulatory status of an MFI has no direct impact on the financial sustainability of an MFI. Additionally, they report that outreach is affected by the level of deposits, implying indirect effect of regulation on outreach if regulation is the only way for MFIs to attract deposits. Hien (2009) supported this assertion where he found that regulatory status has no effect on financial sustainability and outreach of MFIs in Southeast Asia. Similarly, regulation of microfinance has no impact on the financial and outreach performance of MFIs according to Mersland and Storm (2009) when they studied 278 MFIs across sixty countries.

However, regulatory reforms that seek to regulate interest rate by setting interest rate ceilings may seriously affect the financial sustainability and outreach as this move may make it difficult for MFIs to cover their transaction costs. This was the case in Namibia when Adongo and Stork (2006) studied factors influencing financial sustainability of MFIs found that interest rate ceilings caused MFIs to be unsustainable. This was particularly so because the rates were lower than required in order to break - even. It is therefore important for regulators to get the balance right in protecting depositors and clients on MFIs on one hand, and the financial sustainability and outreach of MFIs on the other, in order to continue to contribute to reducing poverty in society.

It is important when discussing regulation of MFIs to point out that many instances the activities of MFIs triggers rush regulation when poor clients are unduly harassed and exploited by these firms. For example, in India, MFIs have been accused of seeking profits at the expense of the poor, attracting stringent regulations that stifled their growth (Purkayastha, Tripathy \& Das, 2014). The government of India of the southern state of Andhra Pradesh in October 2010 passed a new ordinance on the MFIs operating in the state. The ordinance severely restricted the activities of the MFIs operating in the state. The action by the government was in response to the allegations that the aggressive recovery practices followed by MFIs resulted in many of their borrowers' committing suicide (Pouchous, 2012). Since Andhra Pradesh had a major share in the business operations of MFIs, the ordinance increased the non-recoveries of loans given by MFIs. Many big MFIs have stopped operations in the state, while some smaller MFIs closed down completely. The crisis also made it difficult for MFIs to get loans from banks and other financial institutions (Purkayastha \& Rao, 2013) as cited in (Purkayastha, Tripathy \& Das, 2014).

While it is the absence (or near absence) of formal regulation that has long given microfinance the necessary flexibility to develop as a successful financial inclusion tool, this situation has changed gradually over the recent decades (Pouchous, 2012). Indeed, as the sector matures, the arguments in favour of proper regulation (hard and soft) and oversight of microfinance are becoming increasingly substantial. Previous research provides a number of important justifications, including the following: (1) the protection of the country's financial system and small depositors; (2) addressing the consequences of rapid growth and fast commercialization of the microfinance sector; (3) consumer protection and the prevention of MFIs from charging high interest rates that many microfinance industry analysts describes as abusive; (4) the entry of new providers and credit delivery mechanisms in the microfinance sector; (5) lessons from the recent financial crisis; and (6) fraud and financial crimes prevention as reasons for regulating MFIs in recent times (Pouchous, 2012).

Despite its commitment to financial inclusion and poverty alleviation, the practice of microfinance has raised increasing concerns in terms of consumer protection. The rapid commercialization of the industry has largely contributed to this phenomenon (excessive focus on growth and returns instead of asset quality, misleading contractual information, excessive interest rates, among others), but it is not the only reason. Group lending technologies, which form the basis of many microfinance programs, have also led to severe abuses because of their peer pressure mechanism. Examples include aggressive loan collection techniques (for instance, daily harassment, public humiliation, social exclusion, to mention but a few) as well as individual privacy issues. In this context, two main consumer-protection issues are currently the focus of attention of microfinance professionals and regulators. The first concerns abusive lending and collection practices. The second concerns "truth in lending," that is, the delivery of accurate, comparable, and transparent information about interest rates (Pouchous, 2012, p. 13).

As indicated by Mulunga (2010) that the primary responsibility of government in fostering successful 
microfinance is to:

i) Establish appropriate regulations that permit institutions to charge interest and fees needed to cover all costs and to return profits.

ii) Provide effective, appropriate supervision of institutions supplying microfinance.

iii) Educate the bureaucracy and the public about the new microfinance and its importance for the economy and for development.

Consequently, governments in developing countries that understand the social and economic benefits that the country can derive from sustainable microfinance will be better equipped to guide the political processes involved in order to provide an ideal environment for MFIs to operate. As regulators, governments can similarly be a role player in contributing to microfinance sector development through the implementation of appropriate regulatory frameworks (Robinson, 2001 as cited in Mulanga, 2010).

\subsection{Financial Institutions and the Financial Regulatory Framework of Ghana}

Microfinance in Ghana has passed through four distinct phases. The first phase, which started in the 1950s, involved the provision of subsidized credit by the Government. The second phase was the provision of microcredit to the poor through NGOs in the 1960s and 1970s. During this phase, sustainability and financial self-sufficiency were not considered important. The third phase saw the formalization of microfinance institutions, which began in the 1990s. The fourth phase, the current phase, involves the commercialization of microfinance institutions. This started in the mid-1990s and gained much importance with the mainstreaming of microfinance and its institutions in the financial sector (Serrano \& Sackey, 2015).

The financial institutions that are engaged in the provision of microfinance activities in Ghana and the financial regulatory framework that governs these institutions are discussed in this section. MFIs in Ghana consist of a tiered range of formal, semi-formal and informal institutions. In Ghana, the Bank of Ghana (BOG) regulates all financial institutions irrespective of whether it is a formal, semi-formal or informal institution. Yeboah (2010) as cited in Gallardo (2002) indicates that financial intermediation and credit activities fall under the regulatory jurisdiction of the central bank, which is the Bank of Ghana.

In Ghana, it is the Bank of Ghana, which has the overall supervisory and regulatory authority over banking and non-banking financial institutions. The main objective of the Bank of Ghana is to ensure that the operations of the banking and non-banking are efficient and sound in the interest of customers and depositors. The major regulations that are used by the Bank of Ghana in its supervisory and regulatory roles include the following:

1. Companies code (Act 179), 1963

2. Bank of Ghana Act (Act 612), 2002

3. Banking Act (Act 673), 2004

4. Non-Bank Financial Institutions Act (Act 774), 2008

5. Bank of Ghana Notices, Directives, Circulars, and Regulations

Therefore, it is the responsibility of the Bank of Ghana to ensure that the economy of Ghana is stable through an efficient financial system. The Bank of Ghana Act (Act 612) outlines some main functions of the Bank of Ghana including the following:

1. To regulate, supervise and direct the banking system and credit system in order to ensure the smooth operation of a safe and sound banking system

2. To appoint an officer, designate as the head of Banking Supervision Department, who shall be appointed by the Board of the Bank of Ghana

3. To consider and propose reforms of the laws relating to the banking business in Ghana

In Ghana, the financial system is made up of three categories of institutions namely the formal, semi-formal and informal. The formal financial institutions are incorporated under the Companies Code 1963 (Act 179) which makes them limited liability companies and are subsequently licensed by the BOG under either the current Banking Act 2004 (Act 673) as amended in 2007 or Non-Bank Financial Institutions Law 1993 (PNDCL 328) to provide financial services (Yeboah, 2010; Aveh, 2011). The main reason why these institutions are subject to prudent regulation is to provide sufficient protection for the general public savings that are mobilized and lent out by the institutions concerned.

The semi-formal institutions are the Credit Unions (CUs) and the Financial Non-governmental Organisations (FNGOs). These institutions are required to register as legal entities but are not licensed by the Bank of Ghana (Yeboah, 2010). On the one hand, the informal institutions comprise of the susu operators, moneylenders, trade creditors, rotating savings and credit associations (ROSCAs), and the social networks. The informal financial sector is made up of organisations or persons engaged in financial services beyond the scope of banking and formal financial institutions (Aryeetey, 1994; Yeboah, 2010; Aveh, 2011). They are neither licensed nor regulated by the financial regulators and their transactions hardly ever involve any legal documentation, transactions are usually based on verbal and oral agreements (Ashley, 1986; Steel et al., 1997; Yeboah, 2010; Aveh, 2011). However, in recent times due to the fraudulent activities of most operators in the informal sector the Bank of Ghana has shown 
interest in monitoring and supervising these institutions although not stringent enough.

Most important to note is the fact that all these institutions in one way or the other are involved in the provision of microfinance services to the poor in an attempt to reduce poverty in Ghana. It is therefore important that their sustainability and outreach be examined with particular reference to northern Ghana where poverty is wide and deep as the poor in this part of the country has no access to credit from the traditional banking institutions.

\section{Methodology}

This study employed the use of descriptive research design as the study is quantitative. This enabled the researcher to assess the characteristics explained in a research question. The researcher examined whether financial regulation of MFIs influenced their sustainability and outreach in the opinion of managers and operation staff of MFIs in northern Ghana. The use of descriptive research approach was because the study aimed at testing for the correlation between variables and generating a reliable situation profile about the association between these variables.

The population includes all registered MFIs in northern Ghana. The target population is thus the managers and operations staff of these organizations in northern Ghana. The managers and operations staff were chosen because they were considered experienced in the microfinance industry in northern Ghana and they are deemed to have knowledge about the impact of financial regulation on the financial sustainability and outreach of MFIs.

"A sample size is a set drawn from the population"' (Keller, 2009, p.5). Thus, the sample size for this study was determined using formula for sample size determination by Adanza (1995).

That is: $\mathrm{n}=\frac{N}{1+N e^{2}}$

Where: $\mathrm{n}=$ sample size, $\mathrm{N}=$ total population, $\mathrm{e}=$ margin of error; $\mathrm{n}=360 / 1+(0.05) 2(360)=189$, therefore, a minimum of about 189 respondents is desired for this study. In this regard, the study comprised of a sample of at least 189 respondents for the study made of managers and operations staff of MFIs in northern Ghana. In addition, the researcher also sampled 5 staff from the Bank of Ghana northern regional office. The Bank of Ghana staff was selected using purposive and convenience sampling techniques.

As a quantitative study, the researcher employed the structured or closed - ended questions in collecting the research data from the managers and operation staff of MFIs in northern Ghana on their views of factors influencing sustainability and outreach of MFIs. Two sets of questionnaires were developed and distributed. The first set of questionnaires was distributed to 189 managers and operation staff of MFIs sampled in northern Ghana the second set of questionnaires was administered to five (5) officials of Bank of Ghana who were selected using purposive and convenient sampling techniques respectively. The researcher used SPSS 16 in order to test for the reliability with the use of Cronbach Alpha $(\alpha)$. Overall Cronbach's Alpha is 0.892 . This shows a clear indication of very high and strong internal consistency among the variables. The research questionnaires were delivered personally to participants at their work places and the researchers went around again to retrieve answered questionnaires at a later date but this preceded continuous reminder through emails and text messages to institutional heads. The process was time consuming but the findings worth the time consumed in the process.

Participants were duly informed of the purpose, procedure and structure of the study. Right from the start to finish of the data collection, the respondents' interest was preserved and safeguarded. data was analyzed with the aid of Statistical Package for Social Scientists (SPSS) version 16 and Excel 2010 version. After retrieving the answered questionnaires from respondents, the responses were edited in order to check for completeness and accuracy of responses.

\section{Analysis and Presentation of Results}

In order to address the objective of this study, a relationship test was conducted using Spearman multiple correlation on managers and operation staff of MFIs. This technique was necessary in testing for the acceptance or rejection of H1o or H1a. Additionally, description statistics was also used in support. A combination of Spearman multiple correlation and descriptive statistics was also applied on a data set collected on senior staffs from Bank of Ghana.

In examining the respondents' views on the influence of regulation and its impact on financial sustainability and outreach of MFIs in northern Ghana the Spearman multiple correlation results indicated a positive relationship of 0.480 . This is shown in Table 1 .

Table 1

Correlation Between Financial Regulation, Sustainability and Outreach of MFIs in Northern Ghana

\begin{tabular}{llll}
\hline & Outreach & Sustainability & Financial Regulation \\
\hline Outreach & 1 & & \\
Sustainability & 0.09337216 & 1 & 1 \\
Financial Regulation & 0.476693099 & 0.102699382 & 1 \\
\hline
\end{tabular}

As indicated in Table 1, this relationship can only be confirmed by conducting a statistical significance test. Similarly, the coefficient of determination R-square indicates a score of 0.2307 . This is an indication that $23 \%$ of 
variation in the dependent variables, from the view point of managers and operation staff is explained by the independent variable in this case financial regulation. This is shown in Table 2.

Table 2

Regression Statistics Between Financial Regulation, Sustainability and Outreach of MFIs in Northern Ghana

$\begin{array}{ll}\text { Multiple R } & 0.48 \\ \text { R Square } & 0.23 \\ \text { Adjusted R Square } & 0.22 \\ \text { Standard Error } & 0.16 \\ \text { Observations } & 181 .\end{array}$

An analysis of variance test in Table 3 indicates positive statistical relationship between financial regulation (independent variable) and financial sustainability and outreach variables (which are dependent variables) from the point of view of managers and operation staff among MFIs in northern Ghana. This is evident as the level of significance is at $\alpha=0.05>0.0000$.

Table 3

Analysis of Variance (ANOVA) of Financial Regulation of MFIs in Northern Ghana

\begin{tabular}{llllll}
\hline & $d f$ & $S S$ & $M S$ & $F$ & Significance $F$ \\
\hline Regression & 2 & 1.4120 & 0.7060 & 26.6824 & 0.0000 \\
Residual & 178 & 4.7097 & 0.0265 & & \\
Total & 180 & 6.1217 & & & \\
\hline
\end{tabular}

\section{Analysis of descriptive data}

In addition to Spearman, multiple correlations, which indicated a positive statistically significant relationship between regulation (independent variable) and sustainability and outreach (dependent variables) in the views of respondents, a descriptive statistic, was also analyzed of the responses. An assessment on which laws governed the operations of MFIs in northern Ghana, a total of 55 (30.4\%) indicated that the companies code of 1963 (Act 179), whilst astonishingly $126(69.6 \%)$ of the respondents indicated that their MFIs were not governed by the companies' code (Act 179) of 1963. This means that most of the staff of the MFIs either did not understand the question nor did not appreciated regulatory issues well. This is shown in Table 4.

Table 4

Respondents Opinions of Laws Governing MFIs Operations in Ghana

\begin{tabular}{llll}
\hline Law & Response & Frequency & Percent \\
\hline Companies Act, 1963 (Act 179) & Yes & 55 & 30.4 \\
Non-Bank Financial Institutions Act 2008, (Act 774) & No & 126 & 69.6 \\
Bank of Ghana Act 2002, (Act 612) & Yes & 55 & 30.4 \\
& No & 126 & 69.6 \\
Banking Act 2004, (Act 673) & Yes & 76 & 42.0 \\
Other & No & 105 & 58.0 \\
& Yes & 54 & 29.8 \\
\hline
\end{tabular}

One would have expected respondents to appreciate regulatory issues too well considering the levels of educational attainment of respondents from the MFIs. Again, every company operating in Ghana must register with the registrar general's department under the provisions of the companies' code (Act 179) of 1963. On the contrary, when these responses were compared with the responses from the Bank of Ghana it revealed that the companies code (Act 179) of 1963 governed the operations of MFIs in Ghana with 100\% response rate. This is shown in Table 5. This justified the researcher's decision to survey the Bank of Ghana staff since they understood very well regulatory factors and how it in turn affect sustainability and outreach of MFIs in Ghana and in particular northern Ghana. 
Table 5

Respondents Opinions of Laws Governing MFIs Operations in Ghana

\begin{tabular}{llll}
\hline Laws & Responses & Frequency & Percentage \\
\hline & Yes & 5 & 100 \\
Companies Act, 1963 (Act 179) & Total & 5 & 100 \\
Non-Bank Financial Institutions Act 2008, (Act 774) & Yes & 5 & 100 \\
& Total & 5 & 100 \\
Bank of Ghana Act 2002, (Act 612) & Yes & 1 & 20 \\
& No & 4 & 80 \\
Banking Act 2004, (Act 673) & Total & 5 & 100 \\
& Yes & 2 & 40 \\
Others such as Notices and Directives & No & 3 & 60 \\
& Total & 5 & 100 \\
& Yes & 5 & 100 \\
\end{tabular}

Similarly, 55 (30.4\%) again indicated that MFIs are governed by Non-Bank Financial Institutions Act (Act, 774) of 2008 with a striking $126(69.6 \%)$ indicating that MFIs are not governed by the Non-Banking Financial Institutions Act (Act, 774) of 2008. Again, these responses suggest lack of knowledge by majority of the responses as to the sets of regulations governing the operations of MFIs in Ghana. This is shown in Table 4. On the contrary, $100 \%$ of the responses from the Bank of Ghana all indicate that the MFIs are governed by the Non-Bank Financial Institutions Act 2008, (Act 774), thereby agreeing with the minority of the respondents of the MFIs of 30.4\%. This shows that the staff of the Bank of Ghana who are regulators of the MFIs appreciated regulatory issues and its impacts on sustainability and outreach of MFIs in Ghana. This is shown in Table 5.

A total of $76(42 \%)$ of the respondents indicated that MFIs are governed by Bank of Ghana Act (Act 612) of 2002, with 105 (58\%) indicating that MFIs are not governed by the Bank of Ghana Act (Act 612) of 2002. Similarly, $20 \%$ of the respondents from Bank of Ghana indicated the Bank of Ghana Act (Act 612) regulated the operations of the MFIs with $80 \%$ indicating that MFIs are not governed by the Bank of Ghana Act (Act 612). This response rate is consistent with the MFIs responses suggesting that respondents were knowledgeable with respect to the provisions of this Act (Act 612). This is shown in Tables 4 and 5 respectively.

A total of $54(29.8 \%)$ of the respondents indicated that MFIs are regulated by the banking Act (Act 673 ) of 2004 even though MFIs are not banks, whereas $127(70.2 \%)$ of the responses indicated that MFIs are not regulated by the banking Act (Act 673) of 2004. Similarly, 60\% of the respondents from Bank of Ghana indicated that the provisions of this act (Act 673) is not applicable to MFIs since they are not banks. Interestingly $40 \%$ of the Bank of Ghana participants indicated that this Act is applicable to the MFIs. This means that generally the respondents appreciated the laws governing the MFIs in Ghana. This is shown in Tables 4 and 5 respectively.

On the others, $33(18.2 \%)$ indicated that the regulator (Bank of Ghana) occasionally comes up with notices and directives for compliance by MFIs particularly emerging issues that requires interpretation or not covered by existing laws whereas $148(81.8 \%)$ indicated that MFIs do not receive such notices and directives. In comparison, $100 \%$ of the responses from Bank of Ghana indicated that the Bank of Ghana do issue directives and notices to MFIs for compliance. This position from the regulators confirms the minority position of the MFIs respondents and suggest that majority of the MFIs respondents were not aware of such notices and directives. This is shown in Tables 4 and 5 .

Consequently, respondents were also assessed on the interest rates charged by their MFIs operating in northern Ghana. As shown in Table 6, $51(28.2 \%)$ indicated that their firms' charges interest rates on their clients of between $31-40 \%$. Similarly, $50(27.6 \%)$ of the respondents indicated that their MFIs charge interest rates of between $21-30 \%$ on their clients. A total of 20 (11\%) of the respondents indicated interest rates of between $10-20 \%$ are charged by their MFIs while 39 (21.5\%) of the MFIs charged interest rates of less than 9\%. However, 21 $(11.6 \%)$ of the MFIs in northern Ghana charged their clients interest rates in excess of $41 \%$.

Table 6

What are the interest rates charged by your MFIs on your clients?

\begin{tabular}{lll}
\hline & Frequency & Percent \\
Less than $9 \%$ & 39 & 21.5 \\
\hline $10-20 \%$ & 20 & 11.0 \\
$21-30 \%$ & 50 & 27.6 \\
$31-40$ & 51 & 28.2 \\
Over $41 \%$ & 21 & 11.6 \\
Total & 181 & 100.0 \\
\hline
\end{tabular}

The analysis above suggests that MFIs charge very high interest rates on their clients in northern Ghana. This means that the productive poor borrows at higher interest rates which most of these clients may be unable to repay, 
if the amount borrowed is not properly invested in economic activities they can earn return margin equivalent to the interest rates charged on the borrowed funds. Additionally, this implies that the MFIs in northern Ghana equally borrow at such exorbitant rates from the commercial banks particularly those with greater proportion of debt capital as a component of their capital structure, which are passed onto their clients. Thus, any attempt to reduce interest rates may affect adversely on the sustainability and outreach of MFIs.

On the assessment of whether or not existing laws imposed interest rates caps or limits of MFIs operating in northern Ghana, $126(69.6 \%)$ indicated yes while 55 (30.4\%) indicated no. In comparing the responses on the same question from the respondents at Bank of Ghana, 100\% indicated that existing laws on MFIs did not put any cap on interest rates charged by MFIs on their clients. This contradicts the responses from MFIs. In Ghana, currently there is no interest rate caps imposed on MFIs by the regulatory authorities. This means that MFIs staff did not appreciate the question compared with the respondents surveyed from Bank of Ghana. This is shown in Table 7. Table 7

Yes and No Responses on Managers and Operation Staff of MFIs in Northern Ghana

\begin{tabular}{|c|c|c|c|c|c|}
\hline \multirow[t]{2}{*}{ Questions } & \multicolumn{3}{|l|}{ MFIs } & \multicolumn{2}{|l|}{ BOG } \\
\hline & Response & Frequency & $\%$ & Frequency & $\%$ \\
\hline \multirow{3}{*}{$\begin{array}{l}\text { Does existing laws impose interest rates limits (caps) } \\
\text { on your operations? }\end{array}$} & Yes & 126 & 69.6 & - & - \\
\hline & No & 55 & 30.4 & 5 & 100 \\
\hline & Total & 181 & 100 & 5 & 100 \\
\hline \multirow{3}{*}{$\begin{array}{l}\text { Do MFIs have the freedom to charge clients any } \\
\text { interest rates they want? }\end{array}$} & Yes & 60 & 33.1 & 5 & 100 \\
\hline & No & 121 & 66.9 & - & - \\
\hline & Total & 181 & 100 & 5 & 100 \\
\hline \multirow{3}{*}{$\begin{array}{l}\text { Does interest rates charge have effects on MFIs } \\
\text { sustainability and profitability? }\end{array}$} & Yes & 155 & 85.6 & 5 & 100 \\
\hline & No & 26 & 14.4 & - & - \\
\hline & Total & 181 & 100 & 5 & 100 \\
\hline \multirow{3}{*}{$\begin{array}{l}\text { Does existing laws indicate the minimum capital } \\
\text { requirements MFIs need to operate? }\end{array}$} & Yes & 173 & 95.6 & 5 & 100 \\
\hline & No & 8 & 4.4 & - & - \\
\hline & Total & 181 & 100 & 5 & 100 \\
\hline \multirow[t]{3}{*}{ Have MFIs met this capital requirement? } & Yes & 165 & 91.2 & 3 & 60 \\
\hline & No & 16 & 8.8 & 2 & 40 \\
\hline & Total & 181 & 100 & 5 & 100 \\
\hline \multirow{3}{*}{$\begin{array}{l}\text { Has this minimum capital requirement been revised } \\
\text { to a higher amount in the midst of microfinance } \\
\text { scandal in Ghana to offer more protection to MFIs } \\
\text { customers? }\end{array}$} & Yes & 147 & 81.2 & 4 & 80 \\
\hline & No & 34 & 18.8 & 1 & 20 \\
\hline & Total & 181 & 100 & 5 & 100 \\
\hline \multirow[t]{3}{*}{ Will MFIs meet this requirement by the due date? } & Yes & 170 & 93.9 & 3 & 60 \\
\hline & No & 11 & 6.1 & 2 & 40 \\
\hline & Total & 181 & 100 & 5 & 100 \\
\hline \multirow{3}{*}{$\begin{array}{l}\text { Suppose MFIs are unable to meet this capital } \\
\text { requirement will MFIs be compelled to close down } \\
\text { their operations? }\end{array}$} & Yes & 117 & 64.6 & 2 & 40 \\
\hline & No & 64 & 35.4 & 3 & 60 \\
\hline & Total & 181 & 100 & 5 & 100 \\
\hline \multirow{3}{*}{$\begin{array}{l}\text { Do MFIs contribute towards a fund that is meant to } \\
\text { safeguard and protect your clients in case they suffer } \\
\text { losses on their investments? }\end{array}$} & Yes & 36 & 19.9 & - & - \\
\hline & No & 145 & 80.1 & 5 & 100 \\
\hline & Total & 181 & 100 & 5 & 100 \\
\hline \multirow{3}{*}{$\begin{array}{l}\text { Do you think such a fund if introduce will give } \\
\text { clients confidence in the microfinance sector in } \\
\text { Ghana? }\end{array}$} & Yes & 164 & 90.6 & 5 & 100 \\
\hline & No & 17 & 9.4 & - & - \\
\hline & Total & 181 & 100 & 5 & 100 \\
\hline
\end{tabular}

On the assessment of whether MFIs had the freedom to charge their clients interest rates they want in order to achieve sustainability and outreach, the managers and operation staff indicated that MFIs did not have that freedom with $121(66.9 \%)$ response rate whereas $60(33.1 \%)$ indicated that the MFIs had freedom to charge appropriate interest rates in order to be sustainable and to increase outreach both in depth and breadth. On the contrary, $100 \%$ of the respondents indicated that MFIs had freedom to determine interest rates, which will be charged on their clients in order to achieve sustainability and outreach. This further implies that when it comes to regulation majority of the MFIs do not appreciate the issues.

On whether interest rates charged affected or influenced the operations of MFIs in northern Ghana, 155 $(85.6 \%)$ of the respondents indicated that interest rate charged did influence sustainability and outreach whereas $26(14.4 \%)$ indicated that interest rate charged by MFIs did not influence their sustainability and outreach. Comparing these responses to the responses of the Bank of Ghana participants further indicated that $100 \%$ indicated that interest rate charged influenced the sustainability and outreach of MFIs. This is shown in Table 7. On the one hand, a higher interest rate charged by MFIs is thought to lead to achieving sustainability and outreach, 
by the respondents. On the other hand, a higher interest rate charge will be a burden on the productive poor. As a result, most of these poor clients may not be able to repay loanable funds. However, a lower interest rate charged by MFIs may not also lead to the achievement of sustainability and outreach although may be suitable and reasonable to the productive poor clients. Thus, determining appropriate interest rates, which may be just enough for achieving sustainability, outreach, and at the same time considered fair by the clients, is critical to the success of MFIs operations in northern Ghana.

On whether existing laws governing the operations of MFIs indicate the minimum capital requirements needed to operate, $173(95.6 \%)$ indicated that existing laws indicated minimum capital whereas only $8(4.4 \%)$ indicated that existing laws did not indicate minimum capital requirements. Similarly, 100\% of the respondents from Bank of Ghana revealed that existing laws indicated minimum capital requirements suggesting an agreement with responses from MFIs participants. This means that the regulator (the Bank of Ghana) and the MFIs were all aware of capital requirements, which needed to be met if MFIs were to be sustainable in their operations in order to increase outreach to the productive poor.

On whether MFIs met the minimum capital requirement as set by the Bank of Ghana, $165(91.2 \%)$ indicated that they had met the minimum capital requirements, while $16(8.8 \%)$ indicated that their MFIs could not meet the requirements but that they were still working hard to meeting this capital adequacy requirement. A comparison with responses from the Bank of Ghana participants indicates that $60 \%$ of the MFIs met capital requirement, while $40 \%$ indicated MFIs have not met the requirements.

As a result of some scandals in the MFIs industry in Ghana as discussed in literature section of this study, researcher further asked if Bank of Ghana revised the minimum capital requirements. A total of $147(81.2 \%)$ of the respondents indicated that the minimum capital requirement level has been revised while the remainder 34 $(18.8 \%)$ of the respondents indicated that the minimum capital level has not been revised. Similarly, $80 \%$ of the respondents from Bank of Ghana indicate that the minimum capital requirement level has been revised with only $20 \%$ indicating that the minimum capital requirement level has not been revised. These responses as indicated in Table 8 implies that MFIs need to meet new capital requirement levels in order to be more prepared in achieving sustainability and outreach levels.

On whether MFIs will be able to meet this new capital adequacy levels by end of 2018, 170 (93.9\%) indicated that MFIs were confident they will meet this new capital requirement thereby enhancing their sustainability and outreach whereas only $11(6.1 \%)$ indicated that they may not be unable to meet the new capital adequacy requirements. Similarly, a total of $60 \%$ of the Bank of Ghana responses suggest that MFIs will meet the new capital requirement, while only $40 \%$ indicates that MFIs will not meet the new capital requirements. This implies that majority of the MFIs are confident of meeting the new capital requirements and this will enhance sustainability and outreach.

On which date MFIs are expected to meet the new capital adequacy requirements as raised by the Bank of Ghana, 65 (35.9\%) indicated 2016, 42 (23.2\%) indicated 2017, 44 (24.3\%) indicated 2018, while 5 (2.8\%) indicated 2019. A further $25(13.8 \%)$ indicated 2020. This implies that the revised capital adequacy requirement to be met is from 2016-2020. Table 8 indicates the responses as interpreted above.

Table 8

Date MFIs are Expected to Meet the New Capital Adequacy Requirements in the View of Respondents

\begin{tabular}{lll}
\hline & Frequency & Percent \\
\hline 2016 & 65 & 35.9 \\
2017 & 42 & 23.2 \\
2018 & 44 & 24.3 \\
2019 & 5 & 2.8 \\
2020 & 25 & 13.8 \\
Total & 181 & 100.0 \\
\hline
\end{tabular}

As a matter of policy, the Bank of Ghana has issued operating directives to all MFIs operating in Ghana indicating that from January-June 2015 MFIs must raise their capital requirement from GHC100,000 GHC250,000 (USD\$28,571.42- USD\$71,428.57), June 2015 - June 2016 from GHC250,000 - GHC500,000 (USD\$71,428.57-USD\$142,857.14), June 2016 - June 2017 from GHC500,000 - GHC1,000,000 (USD\$142,857.14 - USD\$285,714.29), and as from June 2017 - December 2018 must have at least GHC2,000,000 (USD \$571,428.57). This is shown in Table 9. An average rate of GHc3.50 to USD\$ was used to convert the Ghana Cedis to the US dollar equivalent. As indicated above most of the MFIs have met the current levels and are confident by 2018 they will be meeting the requirement. This suggests that sustainability and outreach levels will be enhanced. The Bank of Ghana made this policy directive in August 2014. 
Table 9

Bank of Ghana August 2014 Directive Requiring all MFIs to Meet Minimum Capital

\begin{tabular}{lllll}
\hline January-June 2015 & June 2015-June 2016 & June 2016-June 2017 & June 2017-December 2018 \\
\hline GHC100,000-GHC250,000 & GHC250,000 & GHC500,000 & - & GHC1,000,000 \\
& GHC500,000 & GHC1,000,000 & GHC2,000,000 \\
\hline
\end{tabular}

This Bank of Ghana believes will enhance the sustainability and improve outreach levels of MFIs in Ghana and in particular northern Ghana where poverty is wide and deep.

The researcher further asked if MFIs would be compelled to be closed down by this regulation if they were unable to meet the new capital requirements. A total number of $117(64.6 \%)$ indicated that MFIs will be closed down while $64(35.4 \%)$ indicated that MFIs will not be closed down even if they failed to meet the capital requirements by the deadline dates. This implies that MFIs, which will not be able to meet the new capital requirements by end of 2018, were likely candidates to be closed down thereby affecting sustainability and outreach. On the contrary, $60 \%$ of the responses from the Bank of Ghana participants indicated that MFIs, which may not meet the new capital requirement levels may not be closed down, while $40 \%$ maintained that MFIs who fails to meet new capital requirement levels may be closed down as indicated in Table 9. This suggests that regulation has a significant influence on the sustainability and outreach of MFIs in northern Ghana in the view of respondents.

As to whether MFIs contributed into a fund that was meant to safeguard and protect their clients in case they suffered losses on their investments, $145(80.1 \%)$ indicated that at the time of responding to the question there was no legal obligation on the part of MFIs to contributes into any fund in order to serve as insurance for their clients should they surfer any loss. This is consistent with the responses from the Bank of Ghana participants $100 \%$ indicated that there was no fund available at the time of filling the questionnaire. This is essential for the sustainability of MFIs and as a result, shortly after the questionnaires were retrieved the government passed legislation called the Deposit Insurance Act, which requires that all customers of MFIs deposit be insured to avoid any loss of deposit with MFIs.

As at the time of data collection, the Government of the Republic of Ghana and MFIs alike had no obligation to contribute money into any fund meant for the protection of the depositors. When asked whether respondents of MFIs thought that such a fund if introduced will give clients protection and be confident in the microfinance industry in northern Ghana. A total number of $164(90.6 \%)$ indicated that the fund will protect and boost confidence of MFIs clients while $17(9.4 \%)$ indicated that the fund will not make any difference with respect to protecting and boosting of MFIs clients' confidence. Similarly, 100\% of the respondents from Bank of Ghana indicated that such fund was necessary in restoring confidence in productive poor clients on the sustainability and outreach of MFIs in northern Ghana. However, this call was timely as the government swiftly pushed the new legislation through Parliament of Ghana requiring that all customers of MFIs deposits are insured and that MFIs themselves must be submitting liquidity information to the Bank of Ghana on monthly basis.

The study examined the extent to which a number of factors influenced MFIs sustainability in northern Ghana from the point of view of the Bank of Ghana participants. This was done using a 5-point Likert scale of 1 no extent, 2 less extent, 3 moderate extents, 4 is great extent, and 5 is very great extent. The following factors were found to influence MFIs sustainability only to a lesser extent;

1)Are licensing and registration procedures too cumbersome for MFIs?

2)Are the supervision and monitoring activities by the Bank of Ghana too loose and ineffective on MFIs operations?

3)Do MFIs pay tax and to what extent does that affect their operations?

This is because the mean scores of these factors were 2.6, 2.4, and 2.6 respectively.

The means scores for the above items were less than the mean average of 3.0 implying that these items are not viewed as critical determinants of MFIs sustainability in northern Ghana in the view of respondents. These are shown in Table 10. The practical implications are that licensing procedures of MFIs are not cumbersome and the Bank of Ghana is properly supervising MFIs. In addition, payment of taxes is corporate social responsibility of MFIs and does not hinder largely the sustainability of MFIs in northern Ghana.

On the other hand, the following questions were found to have moderate influence on the sustainability of MFIs in northern Ghana;

1) Are the supervision and monitoring activities by the Bank of Ghana effective on MFI operations?

2) Do MFIs prepare financial statements?

3) Do MFIs maintain the minimum liquid asset and does it affect their operations?

The above questions had mean scores of 3.4, 3.4, and 3.0 respectively and this is indicated in Table 10 . This indicates that these factors influence MFIs sustainability but only to a moderate extent. This further indicates that supervision and monitoring activities by the Bank of Ghana were effective on the operations of MFIs, and that MFIs prepared their financial statements annually in determining whether they are profitable or not. In addition, MFIs were found to have maintained the minimum liquid asset and does not contribute adversely towards their 
sustainability in northern Ghana in the views of local experts surveyed.

Table 10

Descriptive Statistics of Data from Bank of Ghana Participants

\begin{tabular}{|c|c|c|c|c|c|c|c|c|c|c|c|c|}
\hline & $F 1$ & $F 2$ & $F 3$ & $F 4$ & $F 5$ & F6 & $F 7$ & $F 8$ & $F 9$ & $F 10$ & $F 11$ & $F 12$ \\
\hline Mean & 2.6 & 3.4 & 2.4 & 3.8 & 3.4 & 3.8 & 3.6 & 3.6 & 3.8 & 2.6 & 3.0 & 4.0 \\
\hline Standard Error & 0.6 & 0.4 & 0.4 & 0.8 & 0.7 & 0.8 & 0.9 & 0.9 & 0.8 & 0.6 & 0.3 & 0.4 \\
\hline Median & 2.0 & 4.0 & 3.0 & 5.0 & 4.0 & 5.0 & 5.0 & 5.0 & 5.0 & 2.0 & 3.0 & 4.0 \\
\hline Mode & 2.0 & 4.0 & 3.0 & 5.0 & 4.0 & 5.0 & 5.0 & 5.0 & 5.0 & 2.0 & 3.0 & 5.0 \\
\hline Standard Deviation & 1.3 & 0.9 & 0.9 & 1.8 & 1.5 & 1.8 & 1.9 & 1.9 & 1.8 & 1.3 & 0.7 & 1.0 \\
\hline Sample Variance & 1.8 & 0.8 & 0.8 & 3.2 & 2.3 & 3.2 & 3.8 & 3.8 & 3.2 & 1.8 & 0.5 & 1.0 \\
\hline Kurtosis & 5.0 & 0.3 & 0.3 & 0.3 & 1.5 & 0.3 & -2.5 & -2.5 & 0.3 & 5.0 & 2.0 & -3.0 \\
\hline Skewness & 2.2 & -1.3 & -1.3 & -1.3 & -1.1 & -1.3 & -0.8 & -0.8 & -1.3 & 2.2 & 0.0 & 0.0 \\
\hline Range & 3.0 & 2.0 & 2.0 & 4.0 & 4.0 & 4.0 & 4.0 & 4.0 & 4.0 & 3.0 & 2.0 & 2.0 \\
\hline Minimum & 2.0 & 2.0 & 1.0 & 1.0 & 1.0 & 1.0 & 1.0 & 1.0 & 1.0 & 2.0 & 2.0 & 3.0 \\
\hline Maximum & 5.0 & 4.0 & 3.0 & 5.0 & 5.0 & 5.0 & 5.0 & 5.0 & 5.0 & 5.0 & 4.0 & 5.0 \\
\hline Count & 5 & 5 & 5 & 5 & 5 & 5 & 5 & 5 & 5 & 5 & 5 & 5 \\
\hline
\end{tabular}

A number of questions were found to influence MFIs sustainability in northern Ghana to a great extent. The questions are:

1) Are you required by law to prepare financial statements?

2)Are MFIs financial statements audited

3)Are MFIs required to submit their financial statements to a regulatory body?

4)Do MFIs have internal auditor?

5)Do MFIs have external auditor?

6)To what extent does financially regulations influence MFIs sustainability and outreach in your opinion?

This is so because these questions above had mean scores of 3.8, 3.8, 3.6, 3.6, 3.8, and 4.0 respectively thereby suggesting that the questions were seen as influencing MFIs sustainability from the point of view of managers and operation staff in northern Ghana. This implies that favorable regulation will positively influence MFIs sustainability, whilst too many and tougher regulatory regime may have adverse impacts on the sustainability of MFIs in northern Ghana. Additionally, most MFIs had internal auditors (outsourced) or hired internally and did not have external auditors from the view point of managers and operation staff of MFIs surveyed in northern Ghana, which can have serious implications on risk management practices that may adversely affect the sustainability of MFIs. An MFI with both internal and external auditors were likely to manage risk exposure better and deal with financial constraints better compared to an MFI, which has either internal or external unit only. Similarly, most MFIs struggle to meet deadlines for the submission of their financial statements to the regulatory bodies such as the Bank of Ghana resulting into penalties and fines, which contributes greatly on MFIs sustainability in northern Ghana.

Based on the results above, the study has failed to accept the null hypothesis (H1o), which states that there is no statistically significant relationship between financial regulation of an MFI and sustainability and outreach from the point of view of managers and operation staff surveyed in northern Ghana in favor of the alternative hypothesis (H1a) indicating that there is a statistically significant relationship between financial regulation of an MFI and sustainability and outreach from the point of view of managers and operation staff of MFIs surveyed in northern Ghana.

\subsection{Discussion of the Results}

The results of this study are discussed in relation to the literature on the financial regulation of MFIs and its influence on the sustainability and outreach in northern Ghana.

A number of recent empirical studies provide support to the findings of this study, which show a positive statistically significant relationship between financial regulation and sustainability and outreach in the views of managers and operation staff of MFIs surveyed in northern Ghana. Tehulu (2013) in his study found that MFIs financial sustainability was positively and significantly influenced by ratio of gross loan portfolio to total asset and size. Similarly, Nurmakhanova, Kretzschmar, and Fedhila (2015) found that striking regulation to control and supervise MFIs was considered to improve MFIs financial sustainability, which potentially enhances the level of outreach.

Another study that supports the findings of this study is Kimando, Kihoro and Njogu (2012) who uncovered that financial regulation highly affected the sustainability and outreach of MFIs in Kenya. Hartarska and Nadolnyak (2007) also indicated in their study that financial regulation enhanced the level of outreach, as there was no evidence that regulated MFIs performed less in terms of breadth and outreach. Cull, Demirguc-Kunt and Morduch (2011) asserted that regular supervision of MFIs by regulatory bodies enhances the sustainability and 
outreach of MFIs. Thus, providing a strong support for the findings of this study in northern Ghana, although the authors admitted that compliance with regulation could be costly exercise. On the contrary, to the findings of this study, Pati (2012) found that regulation actually has failed to make any significant impact on sustainability as well as profitability.

Another study contradicting the findings of this study is that of Cull et al. (2011) who found that there is no significant relationship between regulation, measured by four levels of supervision, and financial self-sufficiency. However, the authors did agree that effective supervision would enhance and improve on sustainability. Makame and Murinde (2006) indicate that outreach and MFIs regulations were negatively correlated meaning that regulating an MFI reduces its focus to serving the productive poor clients. While regulation may require that MFIs increase their capital base in order to guarantee depositors of their savings, this can result into a mission drift of an MFI from serving the productive poor clients to rather serving the better-off clients.

Other studies that contradicts the findings of this studies are Purkayastha, Tripathy and Das (2014) who indicate that rigorous and regular supervision although critical for deposit taking institutions such as the MFIs, but it is costly and as such, regulatory supervision thus tends to push MFIs to serve relatively better-off clients as a way of maintaining profitability leading to mission drift. Cull et al. (2011a) also found that profit-oriented MFIs that have complied with prudential supervision respond by curtailing their outreach to segments of the population that are expensive to serve. Hartarska and Nadolnyak (2007) in addition found that there was no direct impact between regulation and MFIs financial sustainability.

\section{Conclusions and Practical Recommendations}

The study found a positive statistically significant relationship between financial regulation and financial sustainability and outreach among managers and operation staff of MFIs surveyed in northern Ghana using Spearman's correlation and descriptive statistics. The study further found that financial regulations of MFIs in northern Ghana affected sustainability and outreach from the point of view of the respondents of MFIs in northern Ghana particularly with respect to capital adequacy requirements and interest rates factors. Based on the findings of the study the following policy recommendations are made:

\subsection{Establishment of Interest Rates Caps}

The study found that $85.6 \%$ and $100 \%$ of respondents from MFIs and Bank of Ghana that interest rates had significant influence on the sustainability and subsequent outreach MFIs. The outcome of this study indicates that at the moment there are no interest rates caps or limits imposed on MFIs in charging their clients. Instead, the MFIs have the freedom to charge any rates deemed appropriate and to keep them sustainable. Furthermore, interest rates generally were found to influence the sustainability and outreach of MFIs in northern Ghana. Based on these findings, the researcher recommends that interest rates caps be introduced thereby determining a ceiling on interest rates MFIs could charge their clients. This proposition is expected to reduce the interest rate from its higher levels. This will also bring about efficiency in the operations of MFIs. There are other ways to be sustainable other than charging higher interest rate in excess of over $41 \%$ as this study revealed.

\subsection{Regular Training of Staff of MFIs}

The researchers recommend that regularly, perhaps quarterly or half yearly the regulatory bodies such as the Bank of Ghana should organize training programmes for the staff of MFIs on issues of regulation and its influence on their operations. This recommendation is derived from the outcome of the study where most MFIs staff did not understand laws governing their operations. The cost of this training must be borne by government because when MFIs fail it is the government that pays the price.

\subsection{Merger of MFIs}

The outcome of this study suggests that not all MFIs are likely not to meet the minimum capital requirement proposed by the Bank of Ghana by the $31^{\text {st }}$ December 2018 deadline. This means that in order not to be closed down due to inadequate capital MFIs are encouraged by the researchers to merge their operations since this will help meet the capital requirement and improve operations efficiently and effectively. Although mergers may bring it associated problems of duplications in operating systems and power struggles as well as integrating challenges, it's still prudent for MFIs if they are unable to meet the capital adequacy requirements on an individual firm level.

\section{Recommendations for Further Research}

There is the need for further research work to be conducted on the causes of high interest rates in Ghana as this is found to be very critical factor affecting the sustainability and outreach of MFIs in northern Ghana.

\section{References}

Adongo, J. and Stork, C. (2005). Factors influencing the financial sustainability of selected microfinance 
institutions in Namibia, The Namibian Economic Policy Research Unit

Annim, S. K. (2012). Targeting the poor versus financial sustainability and external funding: Evidence of microfinance institutions in Ghana. Journal of Developmental Entrepreneurship, 17(3), 1-20.

Annim, S. K. (2010). Microfinance paradigm: Institutional performance and outreach. $\mathrm{PhD}$ thesis, University of Manchester, UK.

Aveh, F. K. (2011). An evaluation of the performance of MFIs in Ghana. DBA thesis, Bradford University, UK.

Ayayi, A. and Sene, M. (2010). What drives microfinance institution's financial sustainability, The Journal of Developing Areas, 44(1), pp: 303-324.

Bogan, V. (2009). Capital structure and sustainability: An empirical study of microfinance institutions, Cornell University, 454 Warren Hall, Ithaca, NY 14853.

Bogan, V. (2011). Financial inclusion, innovation, and investments: Biotechnology and capital markets working for the Poor. Singapore World Scientific, 36-52.

Bogan, V. (2012). Capital structure and sustainability: An empirical study of microfinance institutions. The review of economics and statistics, 94(4), 1045-1058.

Demirguc-Kunt, A., and Morduch, J. (2007). Financial performance and outreach: A global analysis of leading microbanks. Economic Journal, 117, 107-133.

Cull, R., Demirguc-Kunt, A., and Morduch, J. (2011). Does microfinance regulation curtail profitability and outreach? World Development, 39(5), 949-965.

Davutoglu, A. (2013). Two different poverty reduction approaches: Neoliberal market based microfinance verses social rights defender basic income. International Journal of Social Inquiry, 6(1), 39-47.

Demirguc-Kunt, A., and Klapper L. (2012). Measuring financial inclusion: The global findex database. The World Bank Development Research Group, Policy Research Working Paper 6025.

Gallardo, J. (2002). A framework for regulating microfinance institutions: The experience in Ghana and the Philippines. World Bank Policy Research Working Paper 2755, Washington D.C: World Bank.

Ganka, D. (2010). Financial sustainability of rural microfinance institutions in Tanzania, PhD thesis, University of Greenwich, Australia.

Hartarska,V. and Nadolnyak, D. (2007). Do regulated microfinance institutions achieve better sustainability and outreach? Cross-country evidence, 39,1207-122.

Hermes, N., Lensik, R., and Meestres, A. (2011). Outreach and efficiency of microfinance institutions, World Development, 39(6), pp. 938-948.

Kar, A. K. (2013). Mission drift in microfinance: Are the concerns really worrying? Recent cross-country results. International Review of Applied Economics, 27(1), 44-60.

Kindie, B.A. (2012). Financial sustainability of microfinance institutions in Ethiopia, European Journal of Business and Management, 4(15) pp: 1-11.

Kimando, L. N., Kihoro, J. M., \& Njogu, G. W. (2012). Factors influencing the sustainability of microfinance institutions in Murang's Municipality. International Journal of Business and Commerce, 1(10), 21-45.

Makame, A.H., Murinde, V. (2007). Empirical findings on cognitive dissonance around microfinance outreach and sustainability. Finance Working Paper, Birmingham Business School.

Nurmakhanova, M., Kretzschmar, G., and Fedhila, A. (2015). Trade -off between financial sustainability and outreach of microfinance institutions. Eurasia Business and Economics Society, 5, 231-250.

Nyamsogoro, G. D. (2010). Financial sustainability of rural microfinance institutions in Tanzania, PhD thesis, University of Greenwich, Australia.

Omondi, B. E. (2014). The relationship between funding structure and financial performance of microfinance institutions in Kenya. MBA thesis, University of Nairobi, Kenya.

Pati, A. P. (2012). Regulation versus outreach and sustainability: A study of the performance of microfinance institutions in India. The IUP Journal of Bank Management, XI(4), 41-56.

Pati, A. P. (2015). Are regulatory microfinance institutions of India better off than non-regulatory ones? A comparison of performance and sustainability. Sage publications. Available at: http://par.sagepub.com

Pouchous, A. (2012). The regulation and supervision of microfinance: Main issues and progress. Available at: www.iisd.org/tkn

Purkayastha, D. and Rao, A. S. (2013). Microfinance industry in India. Available at: www.icmrindia.org

Purkayastha, D., Tripathy, T., and Das, B. (2014). The impact of regulations on microfinance industry: A strategic perspective. The IUP Journal of Business Strategy, X(3), 25-40.

Quayes, S. (2012). Depth of outreach and financial sustainability of microfinance institutions, Applied Economics, 44(26), pp: 3421-3433. DOI: 10.1080/00036846.2011.577016

Ranjani, K. S. (2012). Regulating microfinance institutions in India: A conceptual framework. Synergy, X(1), 5162.

Schreiner, M. (2002). Aspect of outreach: A framework for discussion of social aspect of microfinance, Journal of International Development, 14, 591-603. 
Tehulu, T. A. (2013). Determinants of financial sustainability of microfinance in East Africa, European Journal of Business and Management, 5(17), pp: 152-158.

Thapa, B, Chalmers, J, Taylor, W, \&Conroy, J. (1992). Banking with the poor, report and recommendations prepared by lending Asian banks and non-governmental organizations, Brisbane, Australia. 